\title{
Elemental Analysis of Dashmool Formulation by ICP-Ms Technique
}

\author{
Saxena Abhishek ${ }^{1}$, Chaudhary Yogita ${ }^{2}$, Singh Manisha ${ }^{2}$, Kumar Vijay $^{2}$ \\ ${ }^{I}$ Director brahmanand group of institution Bulanshahr \\ ${ }^{2}$ Brahmanand group of institutions bulandshahr
}

\begin{abstract}
Multi element analyses were carried out on Dashmool plants using ICP-MS Technique. Zn, Cu, Ni, Mn were screened. The elements present in medicinal plants play an important role in treatment of disease as discussed in Ayurvedas. On the basis of the different results of Dashmool may be more potent against the other disease. Dashmool plants showed the presence of essential elements that could enhance curative process of inflammation.
\end{abstract}

Keywords: Mass Spectrometer, Multi-Elemental Analysis, Dashmool plants

\section{Introduction}

The medical efficacy of Dashmool Plants are attributed to elements present in them.Dashmool is a compound drug used in Ayurvedic System of medicine and this is an ancient formulation used by charak.Dashmool is a combination of ten roots of plants. Botanical name of this plant is Aegle marmelo with the natural order Rutaceae. Dashmool (also spelled as Dashamoola, Dashamula \& Dashamul) is a name given to ten roots of certain plants listed in ingredient section below. The combination of these ten roots is used widely in Ayurveda for many health conditions related to nerves, muscles, bones and joints. It has potent anti-inflammatory, antioxidant and moderate analgesic actions. It is a part of several ayurvedic medicines and alone used for pain disorders and inflammatory diseases related to a musculoskeletal system including osteoarthritis, gouty arthritis and rheumatoid arthritis etc.

\section{Material And Methods}

Sampling- The Various medicinal plants in Table1 were collected in the form of leaves,roots,stembark. The plant Material of dashmool was collected from wild sources in the vicinity of area of University Institute of Pharmaceutical Sciences, Punjab University, Haryana (District /Village -Rewari). All crude drugs were procured from the market and authenticated by Dr. Suresh Baburaj Assistant Director (Botany), Survey of Medicinal Plants and Collection Unit, CCRH, using specifications lay down in Ayurvedic Pharmacopoeia of India. Surface contamination of the plant samples were removed by washing with deionized water twice .The parts of the plant such as root, leaves, stem bark were dried under shade and subsequently ground into fine powder by using mechanical grinder. Analytical grade solvents and chemicals were used for analysis purposes. All other solvents, chemicals and reagents were of purified grade (S.D. fine chemicals or E. Merck India). Distilled water was used wherever water is mentioned. The excipients used in the preparation of the tablets were of pharmacopoeial grade and were selected from the list of permitted excipients published by Government of India, Rule 169, under Drugs and Cosmetics ( $\mathrm{V}^{\text {th }}$ Amendment) Rules, 2005

\section{Quality Standard Parameters Total ash}

Accurately weighed between 2 to $3 \mathrm{~g}$ of the powdered crude drug was incinerated in a silica crucible at a temperature not exceeding $450^{\circ} \mathrm{C}$ until free from carbon in a muffle furnace. The crucibles were taken out, cooled for $30 \mathrm{~min}$ in a dessicator and weighed. The process was repeated until constant weight of ash was recorded in two consecutive weighings.

\section{Uniformity of weight in tablets}

Weighed 20 tablets, selected at random and calculated the average weight. Not more than two of the individual weights should deviate from the average weight by 5 per cent (as tablet weight is more than $250 \mathrm{mg}$ ) as specified in Indian Pharmacopoeia.

\section{Disintegration test of tablets}

The test assembly consists of a rigid basket-rack as per the specified dimensions. One tablet was placed in each tube and perforated plastic discs were placed on the top of the tablets. The basket rack assembly was positioned in a $1 \mathrm{~L}$ beaker of water at $37^{\circ} \mathrm{C} \pm 2{ }^{\circ} \mathrm{C}$. A total of six tablets were subjected to disintegration test. The volume of liquid was such that the wire mesh at its highest point was at least $25 \mathrm{~mm}$ above the bottom of 
the beaker. A standard motor-driven device moved the basket assembly containing the tablets up and down into the beaker through a distance of 50 to $60 \mathrm{~mm}$ at a frequency of 28 to 32 cycles per min.

\section{Hardness of tablets}

The hardness of tablets was checked by placing the tablets between the plungers of Monsanto Hardness Tester. The threaded bolt was screwed up to move the plungers. Pressure was noted when the tablet fractured.

\section{Experimental}

\section{Design of Tablet Formulation of Dashmool}

Dashmool is an Ayurvedic formulation with composition given in table (table 7) below as per 'The Ayurvedic Formulary of India

Dashmool tablets were prepared as per the stated formulation composition in the following steps:

- Preparation of Dashmool blend

- Preparation of Dashmool granules

- Compressing the tablets

\section{Preparation of Dashmool blend}

Crude drug were powdered and passed through a sieve with a nominal mesh aperture of $710 \mu \mathrm{m}$ (sieve no. 22) dependiing on the formulation. All other ingredients of crude drug were also powdered and passed through a sieve with a nominal mesh aperture of $180 \mu \mathrm{m}$ (sieve no. 85) depending on the formulation (excipients). The powder of dashmool and other ingredients were then thoroughly mixed together in a pestle mortar to uniformity. The uniformly mixed powder was then passed through a sieve with a nominal mesh aperture of $710 \mu \mathrm{m}$ (sieve no. 22). This mixture was called dashmool blend.

\section{Preparation of Dashmool granules}

Table 1: Composition of Formulation I

\begin{tabular}{|c|l|c|}
\hline S.No & Ingredients & Quantity per tablet (mg) \\
\hline 1 & Dashmool blend & 250.0 \\
\hline 2 & Dicalcium phosphate & 828.55 \\
\hline 3 & Polyvinylpyrollidone & 50.0 \\
\hline 4 & Talc & 15.0 \\
\hline 5 & Magnesium stearate & 15.0 \\
\hline 6 & Methyl paraben Sodium & 1.16 \\
\hline 7 & Propyl paraben sodium & 0.29 \\
\hline
\end{tabular}

Average weight of tablet $1160 \mathrm{mg}$ containing $250 \mathrm{mg}$ of the active ingredient

- The quantities required for dashmool blend and other pharmaceutical grade excipients from the above table were calculated depending upon the number of tablets (250 tablets were prepared each time) to be prepared.

- The dashmool blend was passed through a sieve with a nominal mesh aperture of $1 \mathrm{~mm}$ (sieve no. 18).

- Polyvinylpyrollidone and dicalcium phosphate were passed through a sieve with a nominal mesh aperture of $250 \mu \mathrm{m}$ (sieve no. 60) and mixed well.

- Dashmool blend, dicalcium phosphate and polyvinylpyrollidone were then mixed geometrically.

- The above mixture was passed through a sieve with a nominal mesh aperture of $1 \mathrm{~mm}$ (sieve no. 18) to obtain granules.

- $\quad$ The granules were dried in a hot air oven for $6 \mathrm{~h}$ at $60^{\circ} \mathrm{C}$.

- The ingredients from serial number 4 to 7 in above table were weighed and passed through a sieve with a nominal mesh aperture of $250 \mu \mathrm{m}$ (sieve no. 60) and mixed well.

- The mixture obtained was then blended together with the granules so obtained after drying.

\section{Compressing the tablets}

The granules were finally compressed into tablets using single-punch tablet machine fitted with the suitable punch and die (either $9.8 \mathrm{~mm}$ convex punch) depending upon the formulation. The above tablet was then evaluated for disintegration time and hardness which revealed the non-compliance of these parameters with the pharmacopoeial limits for tablets. Therefore, some more formulations having dashmool blend as an active ingredient were designed and prepared with the aid of excipients. 
Table 2: Composition of Formulation II

\begin{tabular}{|c|l|c|}
\hline S.NO & \multicolumn{1}{|c|}{ Ingredient } & Quantity per tablet $(\mathrm{mg})$ \\
\hline 1 & Dashmool blend & 125.0 \\
\hline 2 & Starch & 167.1875 \\
\hline 3 & Gelatin & 25.0 \\
\hline 4 & Calpax & 167.1875 \\
\hline 5 & Methyl paraben Sodium & 0.50 \\
\hline 6 & Propyl paraben Sodium & 0.125 \\
\hline 7 & Talc & 7.5 \\
\hline 8 & Magnesium stearate & 7.5 \\
\hline
\end{tabular}

Average weight of tablet is $500.0 \mathrm{mg}$ containing $125.0 \mathrm{mg}$ of the active ingredient.

The above formulations were evaluated for disintegration time and hardness which showed the following results (table 14):

Table 3: Disintegration time and hardness of formulation no. I to VI Formulation I-VI

\begin{tabular}{|c|c|c|c|}
\hline S.No & Formulation & Disintegration(Minutes) & Hardness $(\mathrm{Kg} / \mathrm{cm} 3)$ \\
\hline 1 & I & $6 \min (16 \mathrm{sec})$ & 5 \\
\hline 2 & II & $5 \min (21 \mathrm{sec})$ & 6 \\
\hline
\end{tabular}

Finished Product Specifications Description

The tablets were round, biconcex, grey with diameter $9.8 \pm 0.05 \mathrm{~mm}$ and thickness $5.8 \pm 0.2 \mathrm{~mm}$. They had a bitter taste with an agreeable odour.

\section{Uniformity of weight}

The weight of 20 tablets which were selected at random from a batch had the average weight of $1160 \mathrm{mg}$ for formulation (I), $500 \mathrm{mg}$ for formulation (II).

\section{Uniformity of Formulation}

\section{Formulation 1}

\begin{tabular}{|l|l|l|l|l|}
\hline 1143.2 & 1157.7 & 1190.0 & 1126.7 & 1164.7 \\
\hline 1157.5 & 1157.7 & 1176.1 & 1196.1 & 1138.7 \\
\hline 1189.9 & 1129.9 & 1174.6 & 1194.2 & 1180.5 \\
\hline 1184.5 & 1184.5 & 1110.4 & 1170.4 & 1206.4 \\
\hline
\end{tabular}

\section{Formulation 2}

\begin{tabular}{|l|l|l|l|l|}
\hline 500 & 507 & 510 & 490 & 510 \\
\hline 515 & 505 & 508 & 504 & 504 \\
\hline 502 & 516 & 500 & 510 & 500 \\
\hline 495 & 501 & 516 & 507 & 507 \\
\hline
\end{tabular}

Hardness: $5.0 \mathrm{~kg} / \mathrm{cm}^{3}$ for formulation (I), $6.0 \mathrm{~kg} / \mathrm{cm}^{3}$ for formulation (II),

Friability: $0.15 \%$ for formulation (I), $0.62 \%$ for formulation (II),

\section{Description}

The tablets of dashmool formulations (I) and (II) were round, biconvex, brown to dark brown with diameter $9.8 \pm 0.05 \mathrm{~mm}$ and thickness $5.8 \pm 0.2 \mathrm{~mm}$. They had a bitter taste with an agreeable odour.

Table 4: Physicochemical parameters of Dashmool formulations

\begin{tabular}{|l|l|l|l|l|}
\hline New formulation & Total ash (\%) & $\begin{array}{l}\text { Acid insoluble } \\
\text { ash (\%) }\end{array}$ & $\begin{array}{l}\text { Alcohol-soluble } \\
\text { extractive (\%) }\end{array}$ & $\begin{array}{l}\text { Water-soluble } \\
\text { extractive (\%) }\end{array}$ \\
\hline Aegle marmelos (I) & 5.670 & 0.890 & 7.04 & 7.16 \\
& 5.686 & 0.930 & 7.28 & 7.48 \\
& 5.741 & 0.930 & 7.68 & 7.37 \\
& Mean:5.699 & Mean:0.916 & Mean: 7.33 & Mean:7.336 \\
\hline Clerodendrum & 5.580 & 0.861 & 2.96 & 7.66 \\
phlomidis (II) & 5.686 & 0.831 & 2.64 & 7.88 \\
& 5.741 & 0.819 & 2.88 & 7.92 \\
& Mean:5.669 & Mean:0.837 & Mean:2.826 & Mean: 7.82 \\
\hline
\end{tabular}


Table 5: Different values in $(\% \mathrm{w} / \mathrm{w})$ of various non-metals present in the extracts of various dashmool formulations.

\begin{tabular}{|c|l|l|l|}
\hline Sr.No. & Latin name & Part used & $\mathrm{P}(\% \mathrm{w} / \mathrm{w})$ \\
\hline 1 & Aegle marmelos & Root & 0.2060 \\
\hline 2 & Clerodendrum phlomidis & Root & 1.5900 \\
\hline
\end{tabular}

\section{CHEMICALS}

A Standard solution of each element was prepared by dilution of a 1000mg/l stock solution (Merck) prior to use.Milli pore water was used throughout the experiment. Solvents such as nitric acid ,perchloric acid of analytical grade (Merck) were used.All Glassware were soaked with $10 \%$ nitric acid overnight and ten rinsed with deionized water prior to use.

\section{Digestion Procedure of Dashmool Plants}

$1 \mathrm{gm}$ of each sample was digested in nitic acid/Perchloric acid (6:1) using wet digestion method by heating slowly on a hot plate under fume hood chamber till a white residue was obtained. It was dissolved in $0.1 \mathrm{~N}$ Nitric acid and volume was made upto $10 \mathrm{ml}$. The digested sample were analyzed ICP Instrument.

Table 6: Quantitative list of the elements in different part of the plants

\begin{tabular}{|c|l|l|l|l|l|l|}
\hline Sr.No. & Latin name & Part used & $\mathrm{Cu}(\mathrm{ppm})$ & $\mathrm{N}(\mathrm{ppm})$ & $\mathrm{Mn}(\mathrm{ppm})$ & $\mathrm{Zn}(\mathrm{ppm})$ \\
\hline 1 & Aegle marmelos & Root & 6.21 & 1.48 & 11.42 & 5.51 \\
\hline 2 & Clerodendrum phlomidis & Root & 11.98 & 2.06 & 5.74 & 5.45 \\
\hline 3 & Desmodium gangeticum & Root & 36.41 & 0.01 & 25.9 & 16.51 \\
\hline 4 & Gmelina arborea & Bark & 18.27 & 1.69 & 17.46 & 18.31 \\
\hline 5 & Oroxylum indicum & Bark & 72.86 & 12.57 & 34.92 & 34.04 \\
\hline 6 & Solanum indicum & Bark & 34.88 & 8.34 & 64.14 & 31.5 \\
\hline 7 & Solanum xanthocarpum & Root & 12.58 & 2.58 & 16.5 & 6.97 \\
\hline 8 & Stereospermm suaveolens & Bark & 11.30 & 0.97 & 19.22 & 57.79 \\
\hline 9 & Tribulus terresteris & Root & 30.61 & 2.00 & 21.69 & 26.54 \\
\hline 10 & Uraria picta & Leaves & 12.76 & 2.68 & 99.72 & 19.31 \\
\hline
\end{tabular}

\section{Result And Discussion}

An examination of data from the table indicates that the content of Copper element in Aegle marmelos root $(6.21 \mathrm{ppm})$, Clerodendrum phlomidis root $(11.98 \mathrm{ppm})$. The content of Nickel element in in Aegle marmelos root (1.48 ppm), Clerodendrum phlomidis root (2.06 ppm), The content of Manganese element in Aegle marmelos root (11.42 ppm), Clerodendrum phlomidis root $(5.74 \mathrm{ppm})$. The content of Zinc element in Aegle marmelos root $(5.51 \mathrm{ppm})$ Clerodendrum phlomidis root $(5.45 \mathrm{ppm})$, Zinc is essential for normal development and function of cell-mediating innate immunity, neutrophils, and natural killer cells. Macrophages are also affected by zinc deficiency. Phagocytosis intracellular killing and cytokines production are all affected by zinc deficiency. The growth and function of $\mathrm{T}$ and $\mathrm{B}$ cells are also affected adversely due to zinc deficiency. Zinc is needed for DNA synthesis and RNA transcription and cell activation. Mn phytotoxicity is manifested in a reduction of biomass and photosynthesis, and biochemical disorders such as oxidative stress. Some studies on Mn toxicity and Mn translocation from soil to plant cells in Mn2+ form have demonstrated their importance under low $\mathrm{pH}$ and redox potential conditions in the soil. When $\mathrm{Mn}$ is inside the cells, mechanisms that can tolerate this toxicity are also observed, being important the compartmentalization of this metal in different organelles of shoot and leaf plant cells. A key role of antioxidative systems in plants in relation to high Mn amounts has also been reported as a defense mechanism. Manganese is located largely in the mitochondria. It activates numerous enzymes such as hydrolases, transferases, kinases, and decarboxylases - and is a constituent of some enzymes. One of the most well known manganese metaloen-zyme is pyruvate carboxylase, which catalyzes the conversion of pyruvate to oxalo-acetate 2 . Other enzymes include arginase, which is involved in the conversion of the amino acid arginine to urea, and mitochondrial superoxide dismutase (SOD).The high concentration of copper in the foetal liver is remarkable. Not only is there a massive build up of liver copper in the normal child during the last three months of pregnancy, but the effect lasts about 4 years, by which time liver copper will have normally reverted to adult levels. This build up of liver copper ensures adequate supplies for the infant in the first few months. Despite the absence of convincing evidence it is possible that the concentration of copper in the maternal diet may be involved in determining the rate of growth of the foetus and its post-natal development; in other words the high liver copper may simply be a reflection of the high demand of the foetus for copper. It must be said, however, that growth rates in the newborn appear to be more closely related to zinc than to copper. Above discussed all the elements are having vital role in the all function and need of the body. These all important elements are present in the both formulation so these both formulations may be useful to the human being in the cure treatment and prevention of the many diseases. 


\section{Reference}

[1] Patra A,Mukhopadhyay AK \& Ghosh A,Constitution of Aegle marmelos:Carbon-13 NMR spectra of aurapten and marmin,Indian Journal of Chemistry,Section B : Organic chemistry Including Medicinal Chemistry 17B(4) (1979) 385-7.

[2] Chatterjee A,Sen R \& Ganguly D, On the constitution of the Active principles isolated from the matured bark of Aegle marmelos Correa ,Journal of American Chemical Society 71(1979) 606-609.

[3] 3.Chatterjee A \& Chaudhary B,Occurrence of Auraptene,Umbelliferone,marmin,lupeol and skiammiainine in the root of aegle marmelos corre, Journal of the Indian chemical Society 37(1960) 334-336.

[4] Shoeb A,Randhir S \& Satya P,Coumarins and Alkaloidof Aegle Marmelos, Phytochemical Reports 12 (1973) 2071-2072.

[5] Sharma B.Rattan RK \& Sharma P, Constituents of leaves and fruits of Aegle marmelos, Section B: Organic Chemistry Including Medicinal Chemistry 19B (2) (1980) 162.

[6] Papi Reddy K, Singh AB, Puri A, Srivastava A K \& Narender T, Synthesis of novel triterpenoid (lupeol) derivatives and their in vivo antihyperglycemic and antidyslipidemic acivity, Bioorganic \& Medicinal Chemistry Letters 19(15) (2009) 4463-4466.

[7] Bhattacharya P, Jash SS \& Dey AK, 6',7'-Epoxyacurapatene- a coumarin from Aegle marmelos, Journal of the Indian Chemical Society 66(6) (1989) 424-5

[8] Chatterjee A \& Bhattacharya A, Isolation and constitution of marmin, a new coumarin from Aegle marmelos, Journal of the Chemical Society 22 (199) 1922-4

[9] Goswami S. Gupa V, Sharma A \& Gupta B. D, Supramolecular structure of S-(+) marmesin- a linear dihydrofuranocoumarin, Bulletin of Materials Science 28(7) (2005) 725-729.

[10] Yang X, Masao H \& Tsuneo N, Two new coumarins from the roots of Aegle marmelos, Journal of Chinese Pharmaceutical Sciences 5(2) (1996) 74.

[11] Srivastva S D, Srivastava SK, New anthraquinones from the heartwood of Aegle marmelos, Fitoterapia 67(1)(1996) 83-84.

[12] Ali M S \& Pervez M K, Marmenol: A 7-geranyloxycoumarin from the leaves of Aegle marmelos Corr,Natural Products Research ,2004;18(2):141-146.Nurgroho AE, Riyanto S,Sukari MA and Maeyama K.Effects of Skiammianine , a quinoline alkaloid of aegle marmelos Correa ,on the histamine release from mast cells,Journal of Basic \& Applied Sciences 6(2)(2010) $141-148$.

[13] Shoeb A ,Kapil R S \& Popli SP,Coumarins and alkaloids of Aegle marmelos,Phytochemistry (Elsevier)12(8) (1973) 2071-2.

[14] Bhandari K S \& Gupta Y N ,Chemical examination of essential oil from leaves of Aegle marmelos, Indian Oil and Soap Journal 37(12)(1972) 301-4.

[15] Clerodendrin A,clerodin- Joshi KC et al. A Chemical investigation of the roots of different Clerodendron species. Planta Med 1979; 37: 64-66.

[16] Ethylcholest-5,22E, 25-triene-3ß-ol-Pandey R et al. Lupeol ester from Clerodendrum phlomidis L. Indian J Chem 2008; 47B (3) : 470-472

[17] B-sitosterol-Gupta SK et al. Chemical examination of Clerodendron phlomidis. Indian J Pharm 1967; 28 : 102

[18] Clerosterol-Anam EM. Novel flavanone and chalcone glycosides from Clerodendron phlomidis (Verbanaceae). Indian J Chem 1999; 38B(10) : 1307-1310.

[19] Pectolinarigenin -Subramanian SS et al. Scutellarein and pectolinaringenin from the leaves of Clerodendron phlomides and Duranta repens. Phytochemistry 1972; 11(10) : 3095-3096.

[20] pectolinarigenin, hispidulin, Apigenin, luteolin-Seth KK et al. Flavonoids of Clerodendron phlomidis flowers. Pharmazie 1982; 37(1) : 74-75

[21] 7-hydroxy flavone and 7-hydroxy flavanone 7-O-glucoside-Anam EM. Novel flavanone and chalcone glycosides from Clerodendron phlomidis (Verbanaceae). Indian J Chem1999; 38B(10) : 1307-1310 